УДК 316.35:355.1

Б. О. Носач, аспірант

\title{
СОЦІОКУЛЬТУРНІ КОНТЕКСТИ ВІЙСЬКОВОї ДІЯЛЬНОСТІ
}

Актуальність теми дослідження. Атрибутивною складовою сучасної епохи стає пошук новітніх засобів міжцивілізаційного діалогу, однак в глобалізованому процесі об'єднання та інтеграції спільнот історично-незмінним залишається такий спосіб колективного насильницького перетворення світу як військова діяльність.

Постановка проблеми. Сучасне пропагування тенденції «демілітаризації» соціального життя вимагає формування концептуального підходу заміщення насильницької військової форми з'ясування міжцивілізаційних стосунків прийнятними мирними засобами.

Аналіз останніх досліджень $\boldsymbol{i}$ публікацій. Військова діяльність як матеріальний, предметний та потенційний аспект стає об'єктом дослідження таких мислителів, як Геракліт, Т. Гоббс, М. Кревельд, Ф. Ніцше, З. Фройд, Й. Гейзинга, А. Тойнбі, С. Гантінгтон.

Виділення недосліджених частин загальної проблеми. Проблема дослідження сучасних соціокультурних параметрів фрункціонування сфери військової діяльності в умовах кардинальних змін цифрової епохи недостатньо висвітлена в науковій літературі.

Постановка завдання. Метою даної публікації $є$ аналіз соціокультурних контекстів військової діяльності в умовах розвитку міжцивілізаційного діалогу.

Виклад основного матеріалу. Наш світ сьогодні має соціально-системний характер мережевої комунікації, тому сучасний соціум наглядно уявляє обмежений об'єм природних ресурсів за які можна воювати, але не бажано їх знищувати. 3 самого початку закладалось таке кардинальне протиріччя, яке можна вирішувати виключно у таких соціокультурних контекстах як наука, освіта, мистецтво тощо, котрі допоможуть замінити жорстке знищення людини людиною на предметно-конкретному полі бою $і$ допоможуть перевести військові дії на «шахову дошку» змагання в інтелекті й техніко-технологічному забезпеченні противників.

Висновки. Потенціальним аспектом військової діяльності в системі соціокультурних констант стає зміна речового або енергетичного статусу об'єктів, а в умовах иифрової епохи їх інфрормаційного ресурсу, що забезпечує процес трансфоормації сучасної світової спільноти.

Ключові слова: військова діяльність; культурна ідентичність; соціокультурний простір; війна; людина; соціум; міжцивілізаційний діалог; мілітарна культура.

B. O. Nosach, Postgraduate Student

\section{SOCIOCULTURAL CONTEXT OF MILITARY ACTIVITIES}

Urgency of the research. The main issue on the agenda of modern mankind is the image of the future development of the world economy and peaceful interaction between different parts of the globe, and the concept of the development of cultural identity and the preservation of the identity of a certain community are replacing the model of a unified world..

Target setting. The main in the process of territorial delimitation of state borders, so modern promotion of the trend to "demilitarize" social life requires the formation of a conceptual approach to replace the violent military form of clarifying intercivilizational relations with acceptable peaceful means.

Actual scientific researches and issues analysis. Military activity as a material, objective and potential aspect becomes the object of research of such thinkers as Heraclitus, T. Hobbes, M. Creveld, F. Nietzsche, Z. Freud, J. Huizinga, A. Toynbee, S. Heinington.

Uninvestigated parts of general matters defining. The problem of studying modern sociocultural parameters of the functioning of the sphere of military activity in the context of cardinal changes in the digital era is not sufficiently covered in the scientific literature.

The research objective. The purpose of this publication is to analyze the socio-cultural contexts of military activity in the context of the development of intercivilizational dialogue. 
The statement of basic materials. The war of annihilation is a militaristic activity, which has a destructive character, and each participating country in one form or another receives negative consequences of such confrontation. But the development of the military sphere of activity at a certain stage of human development forms a normative-legal system, which, in turn, creates the basis for the legal regulatory function of culture. From the very beginning, there was a cardinal contradiction that can be resolved only in such socio-cultural contexts as science, education, art, etc., which will help replace the brutal destruction of man by a person on a specific battlefield and help translate hostilities on the "chessboard" competition of intellectual and technical-technological support of the enemy through a preliminary analysis of all components of each other's military capabilities with a potentially calculated winner.

Conclusions. The potential aspect of military activity in the system of sociocultural constants is a change in the speech or energy status of objects, and in the digital era of their information resource, thereby ensuring the process of transformational transformations within the existence of the modern world community.

Keywords: military activity; cultural identity; socio-cultural space; war; man; society; intercivilizational dialogue; military culture.

$$
\text { DOI: 10.25140/2412-1185-2019-2(14)-60-65 }
$$

Актуальність теми дослідження. Головне питання, яке стоїть на порядку денному сучасного людства є образ майбутнього поступу світового господарства та мирна взаємодія між собою різних частин земної кулі, причому на зміну моделі єдино-уніфікованого світу приходять концепції розвитку культурної самобутності, збереження ідентичності певної спільноти та цілісності соціуму. «Якщо соціальні системи описують себе як системи дії, то набувають даного облаштування свободи щодо часу. Тому вони повинні розвивати структури, які здатні зв'язувати події і дії. У цій функції структури мають своє первинне відношення до часу, оскільки зв'язування може здійснюватися лише в часовому вимірі. Іншими словами, така фрорма сприйняття, як «подія», вимушує до експлікації за схемою «раніше» і «пізніше». Без даного «темпорального» зв'язування (яке неможливо замінити ані змістовним, ані соціальним визначенням сенсу) система і навіть дія взагалі зникли б разом з останньою подією, що відбулася. При будь-якій події і дії виникає деякий мінімум несподіванки, а саме зняття того, що «було раніше». Цією мірою новизна конститутивна для емерджентності дії. Проте все нове з'являється, у першу чергу, як одиничне» [1, с. 124], - така думка Н. Лумана включає в себе не просто ідею створення ефективної теорії сучасного соціуму, але й пояснення яким чином відбувається формування соціального порядку в певний відрізок часу, розкривається механізм взаємовпливу двох базових категорій «події» і «дії» як методологічно-універсальної основи будь-якого виду діяльності. Більше того, атрибутивною складовою сучасної епохи стає пошук новітніх засобів міжцивілізаційного діалогу, але в реальному глобалізованому процесі об'єднання та інтеграції спільнот історично-незмінним залишається один з таких способів колективного насильницького перетворення світу як військова діяльність. Відповідно, аналіз проблематики військової діяльності в контексті соціокультурних змін має безперечну актуальність: «соціокультурні особливості держави та ії ідентичність під впливом глобалізації зазнають глибинних трансформацій, стимулюючи розмивання ідентичності, нівелювання (вирівнювання) держав $з$ усіма іншими однорідними державами, залученими до цього процесу. Понад те, процеси подібного нівелювання відбуваються цілком свідомо та цілеспрямовано, як, наприклад у випадку з формуванням європейської ідентичності у межах Європейського Союзу, що всіляко підтримується наднаціональними управлінськими структурами ЄС» [2, с. 142].

Постановка проблеми. Мілітарна культура завжди об'єктивно була однією 3 головних складових цивілізаційного розвитку, а по-суті головною у процесі територіального оформлення державних кордонів, тому сучасне пропагування тенденції «демілітаризації» соціального життя вимагає формування концептуального підходу заміщення насильницької військової форми з'ясування міжцивілізаційних стосунків прийнятними мирними засобами.

Аналіз останніх досліджень і публікацій. Військова діяльність як матеріальний, предметний та потенційний аспект стає об'єктом дослідження таких видатних мислителів різних епох як Геракліт, Т. Гоббс, М. Кревельд, Ф. Ніцше, 3. Фрейд тощо. Тематику співвідношення 
цивілізованого і варварського світів в аспекті військової діяльності представлено у роботах А. Тойнби, а в працях С. Хантінгтона ми зустрічаємо аналіз спільних цивілізаційних цінностей та шляхів збереження культурної ідентичності. Він пропонує одне бачення «світового порядку» $\mathrm{i}$ «образу світу в цілому», головна роль відводиться різноманіттю культур у глобальній взаємодії та відповідно в різноманітності в поведінці, цінностях, віруваннях, тобто проблемам, що вивчаються культурною антропологією [3, с. 77].

Окремо необхідно відмітити суттєвий внесок вітчизняних фрахівців у дослідження проблематики фрілософрії військової справи - це дослідження О. Гуржія, В. Кротюка, В. Мандрагелі, М. Ожевана, Б. Попова, М. Степико, Г. Яворської та багатьох інших. Окрему увагу, з точки зору теоретико-методологічних підходів дослідження, ми звертаємо на ознайомлення з монографрією Б. Парахонського та Г. Яворської, їх теза про те, що «кожний конфлікт має складну природу, яку не можна зводити до зазначених протиріч. Вважається, що у воєнний конфлікт вступають соціальні групи, держави або нації. Соціально-політичний суб'єкт активізується, якщо має певні цілі та відповідну мотивацію. У конфолікті задіяна вся сорера свідомості та емоцій: уявлення, цінності, інтереси, ідеології тощо» [4, с. 399], - підтверджує наявність широкого кола питань зазначеної проблематики.

Умови формування процесів у військовій діяльності, а також вплив на них такої фрорми взаємодії як гра з точки зору феномена загальної культури людства було представлено у працях таких видатних фрілософрів сучасності, як Л. Вітгенштейн, У. Морган, Ф. Ніцше, Х. Ортега-і-Гассет, Ж.-П. Сартр і М. Гайдеггер. Ідеї дослідження ігрового елементу мілітарної культури містять роботи Й. Гейзінги, також можна виокремити дослідження ментальних особливостей у сфері різних фрорм фрізичної діяльності починаючи з середини XX ст. у роботах В. Вундта з психології народів, Л. Леві-Брюля стосовно ментальності архаїчного суспільства, а також праці К. Леві-Стросса, О. Лосєва, В. Проппа, Е. Тейлора, Дж. Фрезера та ін.

Виділення недосліджених частин загальної проблеми. Проблема дослідження сучасних соціокультурних параметрів функціонування сфрери військової діяльності в умовах кардинальних змін цифрової епохі немає достатнього висвітлення у науковій літературі.

Постановка завдання. Метою даної публікації $€$ аналіз соціокультурних контекстів військової діяльності в умовах розвитку міжцивілізаційного діалогу.

Виклад основного матеріалу. У фрілософії військової справи $€$ певне парадоксальне положення: якщо у період військового з'ясування стосунків обидві сторони дотримаються визначених у той або інший період історії цивілізаційного розвитку норм і правил, то тоді війну можна було вважати певною функцією культури або основним елементом змагальних ігор у життєдіяльності спільноти. Розгорнутий аналіз феномену війни в контексті ігрового елемента культури представлений у популярній праці Й. Хейзінга «Homo Ludens. У сутінках наступного дня»: «Одна справа, коли війна ведеться в межах певних правил і норм, які визначаються ворогуючими сторонами. В такому видатку можна вести мову про війну як функцію культури» [5, с. 106]. Безумовно, війна на знищення $€$ мілітарною діяльністю, яка має деструктивний характер (за Гейзінгою агональний), а кожна країна-учасниця у тій або інший формі отримує негативні наслідки такого протистояння. Але розвиток мілітарної сфери діяльності на певному етапі поступу людства фрормує нормативно-правову систему, яка, у свою чергу, створює основу правової регулятивної функції культури.

Дещо інший відтінок свого ставлення до зазначених процесів пропонує нам М. Кревельд: «Війна не $є$ просто засобом, дуже часто розглядалася як мета - крайньою привабливою діяльністю, який неможливо знайти достойне заміщення. Причина, через яку інші види діяльності не зможуть замінити війну, полягає саме у тому, що вони - «цивілізовані»; іншими словами, підпорядковуються штучним правилам. У порівнянні 3 війною, ... всі інші багаточисленні види діяльності, у процесі котрої люди ризикують своїм життям, є просто грою, причому достатньо тривіальною у такому відношенні. Хоча війна також у деякому сенсі «штучний» вид діяльності, вона вирізняється від всього іншого тим, що дарує людині повну свободу, у тому числі, парадоксальним образом, свободу від смерті. Лише війна дає людині можливість застосувати всі його здібності, все поставити на карту і перевірити, чого він вартий у порівнянні з таким самим противником. Саме ставка робить гру серйозною, можливо і благородною» [6, с. 228-229].

Наведені приклади підкреслюють той фракт, що бажання випробувань, дух змагання та 
наявність певних правил створюють основу появи і розповсюдження такого історичного феномену як ініціація. Головною його рисою є просякнутість самої процедури посвячення юнака до військової служби ігровим елементом архаїчної культури, причому феномен ініціації $\epsilon$ присутнім у всіх відомих нам видах культури. «Тут дуже помітна важлива особливість як ініціації, так і мілітарної культури взагалі - формування (становлення) ідеалів справжнього члена спільноти, гідного брати участь у такому випробуванні, як війна - на тлі розгортання опозиції чоловік - жінка. Справді для багатьох культур (але не для всіх) бути повноцінним чоловіком означало бути воїном, вміло володіти зброєю, не боятися випробувань тощо» [7, с. 245], - як бачимо, однією з перших складових мілітарної культури є феномен ініціації, але він виводить нас на таку необхідну сферу існування людини як освітня та виховна діяльність.

Сфера виховання, як така, включає в себе усі види діяльності, так як вона відповідає за формування підростаючого покоління не тільки для подальшого їх залучення до військового захисту своєї країни, а й повноцінної участі у громадських справах мирного періоду життя своєї спільноти. В архаїчних культурах виховна сфера вибудовувалася, як правило, на різного виду випробуваннях, вона мала сакральний характер у формі ритуалів і церемоній. Причому надалі такі процедури набувають характер фіксованого традиційного обряду, які переводять розуміння священного характеру участі у війні на поняття військового обов'язку перед Батьківщиною та воїнської доблесті: «Йдеться про так званий епічний час та сюжет ініціації... Адже епос створює еталон досконалості, ідеальне суспільство, соціальна мета або функція якого - порівняння ідеалу з сучасністю» [8, с. 128].

Надалі, необхідно відмітити роль мілітарної складової в єдиному процесі формування етнокультурних засад певного народу, причому в історичний період його цивілізаційного розвитку. Різницю між цивілізаційним і варварським періодом фрормування народів у контексті військової діяльності розглядає у своїх дослідженнях А. Тойнбі. Він вважає, що такий розподіл зазначених етапів історичного розвитку відбувається у періоді встановлення міждержавних кордонів: «Високий культурний розвиток у різних сферах того чи іншого стародавнього народу як-от персів, єгиптян, греків, римлян, як правило, супроводжувався становленням імперії. Заснування міст-колоній, створення великих армій і флоту, водночас трансляція культурних досягнень у сфері життєдіяльності інших культур - все це етап піднесення цивілізації стародавності. Військові кордони, які можна порівняти з парканом, що наглухо перекриває входи й виходи, сумний фрінал останніх» [9, с. 541], - мова йде про те, що стала цивілізація вже не має змоги рухатися далі та оновлюватися, вона консервує свої досягнення, пробує у такий спосіб захиститися від навколишніх варварських народів, які будуть завжди прагнути нових завоювань та збагачення за рахунок слабкіших сусідів.

Поступово мілітарна сфрера культури стає підґрунтям для історичного процесу фрормування певних нормативів і правил співіснування цілісної спільноти, завдяки чому здійснюється правоворегулятивна функція культури: «Факт, який робить такий шлях розвитку ще більш вірогідним, полягає у тому, що війна є найбільш наслідувана зі всіх відомих людині видів діяльності... Не обов'язково поділяти точку зору Гегеля з приводу пріоритетного положення війни серед всіх людських занять, для того щоб погодитися, що одним 3 важливіших факторів, визначаючих розвиток внутрішній структури будь-якої людської спільноти, була війна людини 3 іншими спільнотами. В кінці кінців, жодна спільнота не ілюструє цього фракту краще, ніж сучасна національна держава - організація, котра набувала свої характерні інститути, включаючи відділені від уряду і народу збройні сили, частково завдяки необхідності воювати з подібними організаціями» [6, с. 204]. Зрозуміло, що новостворені імперії завжди були готові до відсічи загарбницькім намірам, але й варварські військові угрупування дуже швидко освоюють технічні досягнення та навчаються військовому мистецтву. Результатом такої тривалої боротьби стратегій стає поразка практично у всіх відомих нам військових протистоянь цивілізаційних культур.

Отже, така постійна взаємодія зазначених складових призводить до видозмін самої суспільної структури, коли у результаті активного розвитку військової справи фрормується дисциплінований військовий клас з якого виділяється управлінська верхівка державних об'єднань. Поступова зміна військових станів у життєдіяльності суспільства забезпечує подальший розвиток держави як культурного утворення, а етнічні особливості різних форм військового мистецтва та сакральний характер виготовлення зброї сприяли збереженню цілісності спільноти. Починає спостерігатися тенденція переходу від форм військової діяльності 
до процесів державотворення.

Специфіка складових життєдіяльності певних етнічних спільнот впливала на формування особливостей їх мілітарної культури, яка яскраво проявлялася у різних видах вже мистецької діяльності. Здавна нам передавалася інформація у вигляді фольклорних пам'яток про таємниче-сакральний характер предметів військового вжитку. Сюди можемо віднести технології, багато з яких не є розкритими дотепер, виготовлення, оздоблення та зберігання зброї, орнаментів на захисних щитах, військовому спорядженні та інших обладунках. Витворами мистецтва та ознакою етнічної приналежності можна вважати військову форму, тому такі витвори мілітарної культури стають справжніми шедеврами національного мистецтва будь-якого народу.

Сьогодні епоха цифрових технологій вимагає від людини максимальної концентрації її життєвих зусиль тільки в окремій галузі діяльності, так само військова діяльність вимагає колосальних затрат у підготовці спеціалістів різного профілю вже в середині самої військової справи, тому сучасну війну можна виграти тільки колективними зусиллями, використовуючи нові суперсучасні технології. «Комунікаційне середовище створює умови для соціальних обмінів ключовий простір, де породжуються символічні уявлення та закріплюється досвід культури. Владна функція в ньому набуває соціально- інформаційного наповнення і пов'язана 3 можливостями опосередкованого контролю над свідомістю індивіда і соціальної групи. Стан війни, як і стан миру, передбачає формування особливого комунікаційного середовища, створеного засобами спілкування на засадах протистояння і домовленостей» [4, с. 394]. Сьогодні вже (окрім художніх творів) не може бути епічного героя, який один або разом 3 представниками своєї родової спільноти спасає від напасті світ свого існування.

Наш сучасний світ має соціально-системний характер мережевої комунікації, тому сучасний соціум наглядно уявляє обмежений характер своїх природних ресурсів за які можна воювати, але не бажано знищувати. Раніше така природна ситуація існування певної території або перших держав ніколи не враховувалась у постійно-присутніх збройних конфліктах, тоді головним принципом загарбницької політики була думка про те, що сильніший отримує «весь світ», тобто все, що фрізично можна побачити і чим можна скористатися у реальній життєдіяльності. Як у ті часи, так і тепер всі вважають військові дії страшним лихом, але участь у будь-який формі військової діяльності є проявом патріотичного ставлення та любові до своєї Батьківщини. 3 самого початку закладалось таке кардинальне протиріччя, яке можна вирішувати виключно у таких соціокультурних контекстах як наука, освіта, мистецтво тощо, котрі допоможуть замінити жорстке знищення людини людиною на предметно-конкретному полі бою і допоможуть перевести військові дії на «шахову дошку» змагання в інтелекті й технікотехнологічному забезпеченні противника завдяки попередньому аналізу всіх складових військових можливостей один одного з потенційно прорахованим переможцем. У такому випадку можна спробувати змінити світову трагедію знищення життя конкретної людини і постійно продовжувати військову віртуальну Гру як складову міжцивілізаційного діалогу.

Висновки. Військова діяльність як соціально-фрілософське поняття має складно-структурний зміст, відображає майже всі сторони суспільних відносин, будучи водночас їх елементом. Соціокультурними константами військової діяльності ми можемо визначити: історичний перехід від суто мілітарних форм діяльності до процесів державотворення; сферу діяльнісного виховання, що включає в себе героїчний епос або патріотичне відношення до захисту своєї країни; військову науку та відповідну систему освіти; військове художнє мистецтво. Можемо стверджувати, що потенціальним аспектом військової діяльності в системі соціокультурних констант стає зміна речового або енергетичного статусу об'єктів, а в умовах цифрової епохи їх інформаційного ресурсу, забезпечуючи тим самим процес трансформаційних перетворень всередині існування сучасної світової спільноти.

\section{Література}

1. Луман, Н. Час і системна раціональність / Ніклас Луман ; [пер. з нім. та упорядкув. Михайла Бойченка]. - К. : Центр учбової літератури, 2011. - 224 с.

2. Ожеван, М. А. Ноmo ex Machina. Філософські, культурологічні та політичні передумови фоомування конвергентного суспільства: монографрія / М. А. Ожеван, Д. В. Дубов. - К. : НІСД, 2017. - 272 с.

3. Хейнингтон. С. Столкновение цивилизаций / С. Хейнингтон. - М. : Изд-во АСТ, 2003. - 603 с. 
4. Парахонський, Б. О. Онтологія війни і миру: безпека, стратегія, смисл: монографрія / Б. О. Парахонський, Г. М. Яворська. - Київ : НІСД, 2019. - 560 с.

5. Хейзинга, Й. Homo Ludens. В тени завтрашнего дня / Й. Хейзинга. - М. : Издательская группа «Прогресс», «Прогресс-Академия», 1992. - 464 с.

6. Кревельд, М. Трансформация войны / Мартин ван Кревельд. - М. : Издательство ИРИСЭН, 2005. - 242 с.

7. Феномен нації: основи життєдіяльності / за ред. Б. В. Попова. -К. : Товариство «Знання», 1998. - 264 с.

8. Попович, М. В. Мировоззрение древних славян / М. В. Попович. - К. : Наукова думка, 1985. - 168 с.

9. Тойнби, А. Дж. Постижение истории / А. Дж. Тойнби. - М. : Прогресс, 1991. - 802 с.

\section{References}

1. Luhmann, N. (2011). Chas i systemna ratsionalnist [Time and system rationality]. (M. Boichenko, Trans). Kyiv: Tsentr uchbovoi literatury [in Ukrainian].

2. Ozhevan, M. A., Dubov, D. V. (2017). Homo ex Machina. Filosofski, kulturolohichni ta politychni peredumovy formuvannia konverhentnoho suspilstva [Homo ex Machina. Philosophical, culturological and political preconditions for the formation of a convergent society]. Kyiv: NISD [in Ukrainian].

3. Huntington, S. P. (2003). Stolknovenie tsivilizatsiy [Clash of Civilizations]. Moscow: Izd-vo AST [in Russian].

4. Parakhonskyi, B. O., Yavorska, H. M. (2019). Ontolohiia viiny i myru: bezpeka, stratehiia, smys/ [Ontology of war and peace: security, strategy, meaning]. Kyiv: NISD [in Ukrainian].

5. Huizinga, J. (1992). Homo Ludens. $V$ teni zavtrashnego dnya [In the Shadow of Tomorrow: A Diagnosis of the Modern Distemper]. Moscow: Izdatelskaya gruppa «Progress», «Progress-Akademiya» [in Russian].

6. Creveld, M. van. (2005). Transformatsiya voyny [The Transformation of War: The Most Radical Reinterpretation of Armed Conflict Since Clausewitz]. Moscow: Izdatelstvo IRISEN [in Russian].

7. Popova, B. V. (Eds.). (1998). Fenomen natsii: osnovy zhyttiediialnosti [The phenomenon of a nation: the basics of living]. Kyiv: Tovarystvo «Znannia» [in Ukrainian].

8. Popovich, M. V. (1985). Mirovozzrenie drevnikh slavyan [The worldview of the ancient Slavs]. Kyiv [in Ukrainian].

9. Toynbee, A. J. (1991). Postizhenie istorii [Comprehension of history]. Moscow: Progress [in Russian].

Надійшла 30.10.2019

Бібліографічний опис для цитування:

Носач, Б. О. Соціокультурні контексти військової діяльності / Б. О. Носач // Проблеми соціальної роботи: філософія, психологія, соціологія. - 2019. - № 2 (14). - С. 60-65. 